\title{
IMPACT ANALYSIS OF DIGITAL MARKETING: AN INDIAN PERSPECTIVE
}

\author{
Jeet Virendrabhai Madhani ${ }^{1 *}$, Krunal Hareshkumar Rajyaguru ${ }^{2}$ \\ ${ }^{1,2}$ Master of Philosophy, Saurastra University, Rajkot, India. \\ *Corresponding author; Email: 1jeetmadhani@yahoo.com ${ }^{2}$ krunalrajyaguru1@gmail.com
}

\begin{abstract}
The increasing use of digital media by consumers as well as companies, ensures the utilization of digital marketing to reach out to the preferred market segments. The purpose of this study was to determine marketing strategies commonly utilized in digital communication and identify the ones that were most preferred by consumers, which in effect influenced their purchase decisions. Consumers had been identified as the driving force for online shopping. While there had been numerous studies about digital marketing based advertising, there was a little academic research focused on the type of digital marketing strategies that were preferred and influenced consumer's behavior. If provided a personal benefit like discount or reward, they will write an online product review.
\end{abstract}

Keywords: Digital marketing, online advertising, buyer's behavior.

\section{Introduction}

In today's era of technological advancements, marketing practices have been changed from traditional methods to digital marketing. Digital marketing is a tool which can be used for growing the business globally. With the help of digital marketing, a buyer can also compare a product with other product, and it also allows 24 hours of services to purchase, even it allows customers to return a delivered product if they are not satisfied with it.

A customer increasingly uses digital platforms instead of visiting physical shops. Digital marketing movements have become dominant. To use digital marketing tools like Search Engine Optimization (SEO), Search Engine Marketing (SEM), content marketing, campaign marketing, e-commerce marketing, social media optimization, direct email marketing, display advertising have become routine.

In the last decade of $20^{\text {th }}$ century, the term digital marketing was first invented with the debut of server construction and the admiration of personal computers, the Customer Relationship Management (CRM) solicitation became an important plan of marketing plan. Fierce competition forced traders to contain more service into their software, for instance, marketing, sales and service application.

The online marketing strategies observed in this study are pop-up advertisements, side-panel ads, email updates, YouTube videos, and advertising in the form of a game. The website geographies examined in this study are layout, pictures, personalization, prizes, cooperating, offering free items, pricing and return policy. This learning asked Customers to name the publicizing schemes that websites should escape using.

Digital Marketing is often used as 'online marketing' or 'internet marketing'. Now a day's digital marketing term is used in accordance with digital methods for advertising that also connects with digital technologies, mobile phones and display advertising. The method in which digital marketing has developed had changed the way brands and businesses use technology and digital marketing for their marketing (Sathya, 2017).

The differences between traditional marketing and digital marketing in this paper are obtainable. This study has described different forms of digital marketing and the effectiveness of the same. The examined sample consists of one hundred fifty firms and fifty executives who have been randomly selected to prove the effectiveness of digital marketing. Composed data has been analyzed with the help of various numerical tools and techniques (Yasmin, Tasneem, \& Fatema, 2015).

Social media marketing messages are strongly related to social media usage gratifications such as interaction and information, but not entertainment gratification (Chung \& Austria, 2010). Social media content can be used to predict real world outcomes, which demonstrate how sentiments extracted from Twitter can be utilized to improve the forecasting power of social media (Asur \& Huberman, 2010). Similarly, it is shown how social media can be used for predicting the success of a product or service (Lica \& Tuta, 2011). 
There are six steps executives should take in order to dance the social media/viral marketing waltz. They suggest viral marketing as electronic word of mouth whereby some form of marketing message related to a company, brand, or product is transmitted in an exponentially growing way-often through the use of social media applications. They suggest three conditions that are required to be fulfilled to create a viral marketing epidemic (i.e., giving the right message to the right messengers in the right environment) and present four different groups of social media viral marketing campaigns. They conclude with five points of caution that managers should notice when trying to launch their own viral marketing campaign - (1) Viral marketing is only as good as the remaining marketing, (2) Viral marketing needs to be backed up by traditional forms of communication, (3) Excessive planning and intervention kills any viral marketing campaign, (4) Highly proactive and edgy messages are tricky business, and (5) Successful viral marketing requires a little bit of luck and gut feeling (Kaplan \& Haenlein, 2011).

Companies are becoming interested in leveraging consumer-generated content as a valuable digital marketing tool. Firms are proactively trying to induce consumers to spread the word about their products (Godes et al., 2005). It has become a business in itself to provide consumers a venue to voice their opinions. In return for consumer-generated content, some organizations pay cash, give points, or provide some other form of recognition (Chatterjee, 2001).

Customers are increasingly using the Internet for social interactions, work-related tasks, and purchasing. As research shows, consumers do not like advertisements that are distracting, disturbing, forced, or interfere with their work. Based on the preceding review of the literature the following hypotheses were formulated. If we assume that customers do prefer advertisements that are the less intrusive and have an aversion to forced ads, hypotheses 1 and 2 were formulated.

$H_{l}$ : Side panel ads and email ads does have a positive impact on customers.

$H_{2}$ : Unclosed windows and mandatory downloads websites do have a significant impact on customer's preference.

One of the most valuable benefits of using digital media is the capacity of a business to offer consumers a personalized relationship. Since customers have the desire to feel special, hypothesis three was formulated.

$H_{3}$ : Personalized digital marketing does have a significant impact on grabbing the attention of Consumers.
Personal gain has always been a motivating factor in people's lives. Marketers are leveraging this human trait by offering incentives to consumers who will write an online peer review. With this in mind, hypothesis 4 was formulated.

$H_{4}$ : Personal benefit does have significant impact on customers to write peer review.

\section{Research Methods}

The broader objective of this study is to determine which digital marketing strategies are preferred by customers and are effective in influencing their behavior. In this study the attempt is made to analyze the impact of various digital marketing strategies and how it will affect the individual's buying behavior while they are purchasing online and how it is impacting to digital marketing practices and it gives analysis by using various parameters that how you can perform digital marketing functions better by using various marketing strategies and personalization. The research study is analytical and descriptive in nature.

There is consideration of Gujarat State and few areas of India as population size of research study; there will be the sub-geographical urban areas of Gujarat State as sampling units. So, sampling units are city areas of Gujarat State like Ahmedabad, Baroda, Surat and Rajkot.

All the samples are selected haphazardly from the sub-geographical urban areas of Gujarat State. So, the area sampling method was adopted to find the list of respondents for the research study.

In this research study, 225 respondents have been considered to measure an impact of digital marketing; a customer's perspective among them. The data of demographic variables of respondents like - age, sex, educational qualification, profession and monthly income have been recorded. This study is based on primary data though secondary data is gathered. All the samples are selected haphazardly from the sub-geographical urban areas of Gujarat State. So, the area sampling method was adopted to find the list of respondents for the research analyses.

For the primary data, a well-structured questionnaire was developed after an extensive review of preferable marketing strategies and digital marketing pieces of literature. The secondary data needed for the study were collected from the relevant online thesis, online research articles, journals, books, magazines and websites. A well-structured questionnaire was developed after an extensive review of preferable marketing 
strategies and digital marketing pieces of literature. Responses were made on a Likert scale, with 1 representing 'strongly disagree' and 5 representing 'strongly agree'. Reliability test has been done to know the data reliability. The data have been tested with Chi-Square test at $5 \%$ of significance level to test all the hypotheses through statistical software SPSS.

\section{Results and Discussion}

$H_{l}$ : Preferred forms of online advertising.

To determine which digital marketing strategies customers dislike, survey participants indicated their level of agreement to a series of statements. Results do support hypothesis 1 . Responses revealed that side panel advertising or mail advertising is preferable digital marketing strategy that marketers should utilize. The test result has been shown in Table 1 .

Table 1

Chi-Square Test Result for Hypothesis 1

\begin{tabular}{lccc}
\hline & Value & $d f$ & $\begin{array}{c}\text { Asymp. Sig. } \\
\text { (2-sided) }\end{array}$ \\
\hline Pearson Chi-Square & $48.186^{\mathrm{a}}$ & 12 & .000 \\
Likelihood Ratio & 46.239 & 12 & .000 \\
Linear-by-Linear & 1.397 & 1 & .237 \\
$\quad$ Association & & & \\
$N$ of Valid Cases & 225 & & \\
\hline
\end{tabular}

$\mathrm{H}_{2}$ : What to avoid in digital marketing.

Results strongly supported hypothesis 2. Responses revealed that customers disliked marketing strategies like un-closed windows and mandatory downloads. Marketer should avoid such marketing strategies. The test result has been shown in the Table 2.

Table 2

Chi-Square Test Result for Hypothesis 2

\begin{tabular}{lccc}
\hline & Value & $d f$ & $\begin{array}{c}\text { Asymp. Sig. } \\
\text { (2-sided) }\end{array}$ \\
\hline Pearson Chi-Square & $66.748^{\mathrm{a}}$ & 12 & .000 \\
Likelihood Ratio & 64.599 & 12 & .000 \\
Linear-by-Linear & .010 & 1 & .921 \\
$\quad$ Association & & & \\
$N$ of Valid Cases & 225 & & \\
\hline
\end{tabular}

$H_{3}$ : Personalized digital marketing does have a significant impact on grabbing the attention of Consumers.

Respondents have fully supported hypothesis 3 . Responses revealed that the digital marketing strategy that overwhelmingly grabs the attention of customers is preferred. Personalization on a website grabs the attention of customers. They believe that personalized digital media ads are more convincing than print media ads, and personalization also affects their buying behavior while they are purchasing online.

Table 3

Chi-Square Test Result for Hypothesis 3

\begin{tabular}{lccc}
\hline & Value & $d f$ & $\begin{array}{c}\text { Asymp. } \\
\text { Sig. (2- } \\
\text { sided) }\end{array}$ \\
\hline Pearson Chi-Square & $32.033^{\mathrm{a}}$ & 12 & .001 \\
Likelihood Ratio & 32.493 & 12 & .001 \\
Linear-by-Linear & 1.122 & 1 & .290 \\
$\quad$ Association & 225 & & \\
$N$ of Valid Cases & & & \\
\hline
\end{tabular}

$H_{4}$ : Personal benefit does have a significant impact on customers to write peer review.

Respondents have fully supported hypothesis 4 . Respondents have revealed that personal benefit like coupons, rewards or reward points does influence to write peer review about the product or service.

Table 4

Chi-Square Test Result for Hypothesis 4

\begin{tabular}{lccc}
\hline & Value & $d f$ & $\begin{array}{c}\text { Asymp. Sig. } \\
\text { (2-sided) }\end{array}$ \\
\hline Pearson Chi-Square & $35.409^{\mathrm{a}}$ & 12 & .000 \\
Likelihood Ratio & 36.299 & 12 & .000 \\
Linear-by-Linear & 1.450 & 1 & .228 \\
$\quad$ Association & 225 & & \\
$N$ of Valid Cases & & & \\
\hline
\end{tabular}

\section{Conclusion}

While there have been many studies about online marketing, there has been tiny academic research attentive on what variety of digital marketing plans are preferred by customers and which ones impact their performance. Customers are an essential ingredient in the development of e-commerce. Results of this study indicate that customers prefer certain forms of digital advertising while avoiding others. Results also indicate that there are digital marketing plans that are significantly much efficient as compared others in getting the attention of customers, inspiring repeat visits to a website, and asking online reviews. Data for the study were obtained via a study of 225 customers. In planning digital advertising, marketers should use sidepanel ads and suggest coupons if they need to appeal to customers. 
This group also likes viewing announcements on YouTube. Do not use pop-up advertising or un-closable windows, except your committed is to irritate the customer. Customers are concerned to a website with luminously colored textures. Digital media suggest the chance to personalize websites and advertisements; marketers should take full benefit of this feature. This group likes the individual ability and the chance to network with the marketer. Make your website communicative. Also make your website modest on prices and shipping rates, as these are the top influencers for customers continuously visiting a website. Online appraisals are very influential, especially with customers. Encourage customers to write online reviews by giving them a discount as an incentive. This group does not reply well to rewards. A 'freebie' may be a little price to pay in return for a good review that is read by frequent Internet shoppers.

By taking into consideration the preferences of customers, a company can increase the effectiveness of its digital marketing aimed at this market segment. A company should not use online advertising that is measured troubling and irritating, thus revolving away customers. Companies can influence customers by identifying which digital marketing strategies are appealing and can get you a quick repeat business. Of course, satisfying the customers must be the first order of business in order to receive a positive review. To promote a brand or company a marketer can utilize the consumer-generated content. Companies should join with this new group of consumers on their orbit, the digital arena; this will enable successful communications.

\section{References}

Asur, S., \& Huberman, B. A. (2010). Predicting the future with social media. 2010 IEEE/WIC/ACM International Conference on Web Intelligence and Intelligent Agent Technology, 492-499.

Chatterjee, P. (2001). Online reviews - Do consumers use them? In M. C. Gilly and J. Myers-Levy, $A C R$ 2001 proceedings (pp. 129-134). Provo, UT: Association for Consumer Research.

Chung, C., \& Austria, K. (2010). Social media gratification and attitude toward social media marketing messages: A study of the effect of social media marketing messages on online shopping value. Proceedings of the Northeast Business \& Economics Association, 6(1), 581-586.

Godes, D., Mayzlin, D., Chen, Y., Das, S., Dellarocas, C., Pfeiffer, B., Libai, B., Sen, S., Shi, M., \& Verlegh, P. (2005). The firm's management of social interactions. Marketing Letters, 16(3/4), 415-428.

Kaplan, A. M., \& Haenlein, M. (2009). The fairyland of second life: Virtual social worlds and how to use them. Business horizons, 52(6), 563-572.

Lica, L., \& Tuta, M. (2011). Predicting product performance with social media. Informatica Economica, 15(2), 46-56.

Sathya, P. (2017). A study on digital marketing and its impact. International Journal of Science and Research, 6(2), 866-868.

Yasmin, A., Tasneem, S., \& Fatema, K. (2015). Effectiveness of digital marketing in the challenging age: An empirical study. The International Journal of Management Science and Business Administration, 1(5), 69-80. 